\title{
ISOTOPE GEOCHEMISTRY AND PETROLOGY OF THE
} AFRICAN CARBONATITES

Kanenori Suwa*, Shinya Oana*, Hideki Wada* and Susumu Osaki** *Department of Earth Sciences, Faculty of Science, Nagoya University, Nagoya, Japan

** Department of Chemistry, Faculty of Science, Kyushu University, Fukuoka, Japan

Many carbonatite bodies were emplaced in the African continent since Precambrian period.

Measurements of oxygen and carbon isotopes of the various kinds of the African carbonatites were performed to elucidate the conditions of formation of the carbonatites, and to elucidate the variation of the isotope ratios in rocks which have been affected by late-magmatic hydrothermal and deuteric processes, and to come to firm conclusions about the ultimate origin of the carbonatite.

The carbonatite bodies examined are Precambrian Phalaborwa and Premier carbonatites, Mesozoic Spitskop and Mbeya carbonatites, Tertiary Homa Mountain carbonatites and Recent Oldoinyo Lengai carbonatite.

The results of oxygen and carbon isotope analyses are expressed as the per mil deviation of the ${ }^{18} \mathrm{O} /{ }^{16} \mathrm{O}$ and ${ }^{13} \mathrm{C} /{ }^{12} \mathrm{C}$ ratios from the ratios in SMOW and $\mathrm{PDB}$ standards, respectively.

\section{(1) Precambrian Phalaborwa carbonatite:}

The Phalaborwa carbonatite is located near the north-east border of South Africa, and is Middle Precambrian (2060 m. y.) in age.

The carbonatite occurs in the centre of the Phalaborwa Igneous Complex, mainly composed of diopside-pyroxenite.

The two principal types of carbonatite are an olde $r$ banded sbvite and a younger transgressive sbvite. There is no clean-cut division between the older sbvite and phoscorite. The younger sbvite forms a well-defined but irregular intrusion in the central part of the pope as well as a series of narrow dikes or offshoots.

Four calcite sampless from the carbonatites we re analysed. Older sbvite shows $\delta{ }^{18} \mathrm{O}: 8.05 \% 0, \delta{ }^{13} \mathrm{C}:-4.28 \%$. Younger sbvites show $\delta{ }^{18} \mathrm{O}: 8.10 \sim 10.24 \%, \delta^{13} \mathrm{C}:-3.10 \sim-3.94$ $\%$.

The field of oxygen and carbon isotope ratios of the Phalaborwa carbonatite, especially of older carbonatite, coincides with that of primary igneous carbonatites. 
(2) Precambrian Premier carbonatite :

The Premier carbonatite (Premier Diamond Mine) is located near Pretoria in South Africa, and is Middle Precambrian ( $1750 \pm$ $100 \mathrm{~m} . \mathrm{y}$. ) in age.

The Premier Mine kimberlites are extraordinarily rich in calcium carbonate, and the kimberlites have been named according to the predominant matrix colour: Grey, brown, black, green, orange, pale grey, fawn and blue kimberlites.

The main carbonatite dike mass intruded the centre of the Black kimberlite. The carbonatite dike consists essentially of anhedral grains of calcite, fine-grained granular magnetite and some interstitial serpentine. The Black kimberlite consists of very dark, almost black, aphanitic rather uniform material, in which occurs ilmenite, serpentinized phenocrysts of olivine and, less commonly, garnets and chrome-diopside.

Carbonatized varieties of Black kimberlite, named "Pale Piebald" and "Dark Piebald", occur in the kimberlite surrounding the carbonatite dikes.

Three calcite samples from the carbonatite, "Pale Piebald" and Black kimberlite were analysed : $\delta 180: 12.44 \sim 13.29 \%$ ${ }^{13} \mathrm{C}: \quad-5.99 \sim-6.97 \%$.

Of considerable interest are these data that the Premier carbonatite in kimberlite pipe shows strong similarities with the primary hydrothermal calcite ( Calcite I) formed at about $360^{\circ} \mathrm{C}$ at the Providencia, Mexico (Rye, 1966).

This calciferous dikes described by Daly ( 1925 ) cannot be regarded as true carbonatite. They were probably formed by replacement of a kimberlite variety already rich in $\mathrm{CaCO}_{3}$.

(3) Mesozoic Spitskop carbonatite :

The Spitskop carbonatite is located in north-eastern part of South Africa, and is to be believed as a late-Karroo age.

The Spitskop Alkaline Complex is mainly of ijolite intruded by two great foyaite ring-dikes and by a central plug of carbonatite.

Four varieties of carbonatite have been distinguished ( Verwoerd, 1966):

(a) White sbvite occurs presumably continuous, outer zone on all sides of the plug.

(b) Grey dolomite-sbvite is intermediate in position as well as composition between the white sbvite and beforsite.

(c) Beforsite forms the bulk of the Spitskop carbonatite.

(d) Apatite-rich carbonatite occurs in beforsite as well as in dolomite-sbvite along three concentric horizons.

Nine calcite, ankerite and dolomite samples were analysed. Calcites in dolomite-sbvite show $\delta^{18} \mathrm{O}: 11.71 \sim 12.30 \%$, ankerites in beforsite and apatite-rich beforsite show $\delta^{18} \mathrm{O}: 16.54 \sim$ $17.54 \%$ and $\delta^{13} \mathrm{C}:-1.96 \sim-2.49 \%$, later stage calcite and 
dolomite show $\delta 180: 17.50$ and $18.35 \%$, and $\delta^{13} \mathrm{C}:-2.34$ and $-1.99 \%$, respectively.

Spitskop carbonatite shows a slight deviation from that of primary igneous carbonatites. The Spitskop carbonatite is regarded as a pipelike body of which the composition was modified after emplacement by circulating fluids in several stages marked by progressive enrichment in magnesium and iron.

The isotope fractionation among coexisting minerals in later stage carbonate vein indicates $320^{\circ} \mathrm{C} \sim 660^{\circ} \mathrm{C}$.

(4) Mesozoic Mbeya carbonatite:

The Mbeya carbonatite is located near the south-west border of Tanzania, and is Cretaceous in age.

Fifty two calcite and dolomite samples were analysed.

Calcite and dolomite samples from unaltered carbonatites lie in a small field low in $\delta^{18} \mathrm{O}\left(5.9 \sim 7.7 \%\right.$ ) and low in $\delta^{13} \mathrm{C}(-3.6 \sim$ $-5.3 \%$ ), this field coincides with that of primary igneous carbonatites. Carbonates coexisting with abundant metal oxides become enriched in ${ }^{18} \mathrm{O}$ (Suwa, et al., 1969).

The fractionation factors of oxygen and carbon isotopes between the coexisting calcites and dolomites in the carbonatites range from 0.07 to $0.64 \%$ and from 0.20 to $0.59 \%$, respectively, suggesting that the carbonates crystallized at temperatures $800^{\circ} \mathrm{C} \sim 380^{\circ} \mathrm{C}$ and $>700^{\circ} \mathrm{C} \sim 380^{\circ} \mathrm{C}$, respectively.

(5) Tertiary Homa Mountain carbonatites:

The Homa Mountain carbonatite is located near the north-eastern coast of Lake Victoria, and is Miocene in age.

Commencing with the first intrusion of ijolite suite, the following five main types of carbonatite are thought to be the sequence of intrusions and extrusions at Homa Mountain (Clarke, 1968 ).

C 1 : Coarse-grained sbvites

C 2 : Medium-grained alvikites

C 3 : Purple rhomb carbonatites

C 4: Ferruginous carbonatites

C 5 : Carbonated melilitites

Twenty eight calcite samples from the carbonatites and related rocks were analysed.

The field of oxygen $(7.99 \sim 9.16 \%$ ) and carbon $(-5.12 \sim$ $-4.17 \% 0$ ) is otope ratios of unaltered sbvite ( C 1 ) samples coincides with that of primary igneous carbonatites.

Calcite samples in carbonatites ( C 2, C 3, C 4, C 5 ) and their related rocks are enriched in $180(8.10 \sim 29.11 \% 0)$, and these are altered and/or formed in relation to one or more cycles of younger hydrothermal activity, brecciation and mixing accompanied by explosive activity, and weathering. 
(6) Recent Oldoinyo Lengai carbonatite :

Oldoinyo Lengai is an active volcano in northern Tanzania and yielded lavas of high alkali carbonatite in its 1960 and 1961 eruptions (Dawson, 1962 a, b).

Five sodium carbonate samples collected by J. B. Daws on in 1960 were analysed.

The sample, ground to minus 200 mesh, is dissolved in 0.04 mole/ $1 \mathrm{NaOH}$ solution and immediately $\mathrm{CaCl}_{2}$ is added to the solution in order to precipitate $\mathrm{CaCO}_{3}$. This $\mathrm{CaCO}_{3}$ is used for isotopic analysis.

Sodium carbonate lava is deliquescent and is easily affected in air. Unaltered samples, inner part of the specimen, show ${ }^{18} \mathrm{O}$ : 6. $17 \sim 6.37 \%$, $\delta^{13} \mathrm{C}:-10.22 \sim-9.65 \%$.

The lower value of $\delta{ }^{13} \mathrm{C}$ in the sodium carbonate lava is due to the violent explosion of $\mathrm{CO}_{2}$ gas having heavy carbon during vulcanicity and the reby carbon remaining in the form of sodium carbonate becomes lighter. At temperature between $300^{\circ} \mathrm{C}$ and $800^{\circ} \mathrm{C}$, carbon in $\mathrm{CaCO}_{3}$ coexisting with $\mathrm{CO}_{2}$ gas is lighter than carbon in the $\mathrm{CO}_{2}$ gas as $2 \sim 3 \%$ o (Bottinga, 1968).

\section{References}

Bottinga, Y. ( 1968 ): J. Phys. Chem., vol. 72, $800-808$.

Clarke, M. C.G. ( 1968 ): Ph. D. Thesis (Manuscript), Univ.

Leicester, 1 - 291 .

Daly, R.A. ( 1925 ): J. Geol., vol. 33, 659 - 684.

Dawson, J. B. ( 1962 a) : Nature, vol. 195, 1075 - 1076.

Dawson, J. B. ( 1962 b) : Bull. Volcanol., vol. 24, 349 - 387.

Rye,R.O. ( 1966 ): Econ. Geol., vol. 61, 1399 - 1427.

Suwa, K., Osaki, S., Oana, S., Shiida. I., and Miyakawa, K. (1969):

J. Earth Sci., Nagoya Univ., vol, 17, 125 - 168.

Verwoerd, W. J. ( 1966 ): Ann. Univ. Stellenbosch, vol. 41, ser.A, No. 2, $115-233$. 